\title{
Rare Case of Gallbladder Adenomyomatosis in Female
}

\author{
Authors \\ Dr Shahaji Chavan, Dr Vinayak Kshirsagar, Dr Sagar R. Ambre, Prajakta Deodas \\ (Final Year Student MBBS)
}

\begin{abstract}
Adenomymatosis of gallbladder is a benign condition. Adenomymatosis of gallbladder is tumor like lesions that are found in 2\% of all cholecystectomies. Adenomyomas are characterized by ROKITANSKY ASCHOFF SINUSES. Adenomymatosis is incidental finding on USG. We report a case of symptomatic adenomymatosis of the gall bladder.

KEYWORD-Adenomymatosis of gall bladder, symptoms, treatment.
\end{abstract}

\section{INTRODUCTION}

Adenomymatosis of gall bladder is a benign condition ${ }^{(1,3)}$.Adenomymatosis is tumor like lesion that are found in $2 \%$ of cholecystectomies $^{(1)}$.it is mainly seen in gall bladder, it may seen in stomach, small intestine ${ }^{(2,5,6)}$. Adenomymatosis of gall bladder isdegenrative condition in which gall bladder wall thickend and mucosa of gall bladder is also thickened it is also called ROKITANSKY ASCHOFF SINUSES $(\mathrm{RAS})^{(6)}$. Adenomymatosis is incidental finding either USG is performed for right upper quadrant pain $^{(6)}$.We report a case with 65 yr female with diagnosis of adenomymatosis as it is a rarely encounterd entity.

\section{CASE REPORT}

A 65 year female was came to OPD with right upper quadrant pain. The pain was colicky and associated with food intake.patient give history of pain since 1 year.since last 5 month pain was more for which she was taking medication but pain become more frequent. There is no history of any surgery or truma to abdomen in past. On physical examination mild tenderness present in epigastric and right hypochondrium. Laboratory investigation showed several abnormal findings, including leukocytosis $(14500$ cells $/ \mu \mathrm{L}$; reference range $[R R], 4500-11000$ cells $/ \mu \mathrm{L})$ and elevated aspartate aminotransferase (61 U/L; RR, 10-42 $\mathrm{U} / \mathrm{L})$ and alanine aminotransferase (75 U/L; RR, 10-40 U/L) levels. Ultrasonography of the abdomen revealed marked thickening of the gallbladder wall. However, serum bilirubin (0.4 $\mathrm{mg} / \mathrm{dL} ; \mathrm{RR},<1.5 \mathrm{mg} / \mathrm{dL}$ ), alkaline phosphatase (140 U/L; RR, 40-140 U/L), and gammaglutamyl transpeptidase (59 U/L; RR, 8-61 U/L) levels were normal. Initially, acute atypical cholecystitis with fever as the only symptom was diagnosed, and empirical antibiotic therapy was indicated (intravenous infusion of ceftazidime [2000 mg] 3 times per day), Magnetic resonance imaging (MRI) was performed to clarify the nature of the gallbladder lesion and showed evident thickening of the epithelial and muscular elements and multiple intramural cysts of various sizes. Patient 
was posted for cholecytectomy and specimen was sent for HPE.Histopathological examination showed ROKITANSKY ASCHOFF SINUSES with thickened musculosa. ROKITANSKY ASCHOFF SINUSES is typical for adenomyomatosis of gall bladder. Patient remained symptom free after cholecystectomy and was discharged on $9^{\text {th }}$ day of operation. Patient is called for followup for every 6 month in OPD there is no sign of any complication till now.

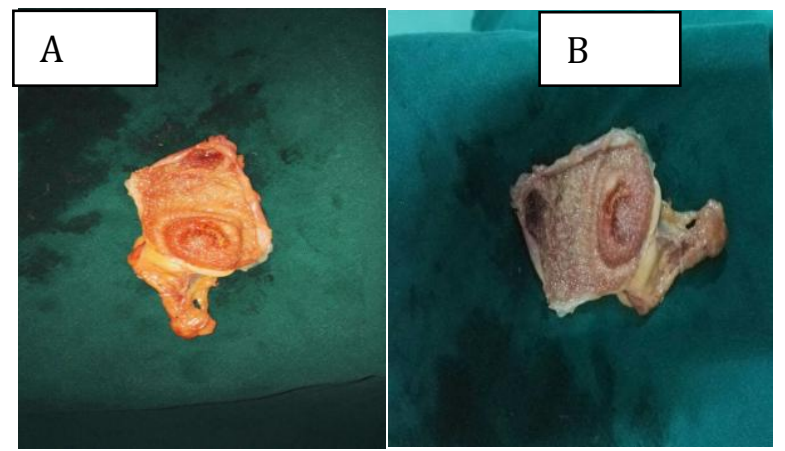

Surgery specimen showing a huge gallbladder with multiple intramuscular cysts

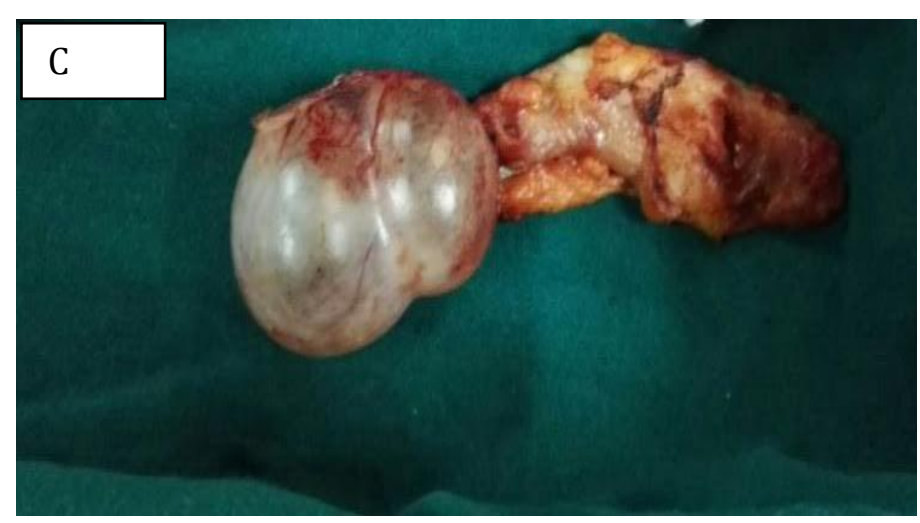

Surgery specimen showing a huge gallbladder

\section{DISCUSSION}

Adenomymatosis of gall bladder is incidental finding on $\mathrm{USG}^{(6)}$. The term was introduced by JUTRAS et al in $1960 .^{(7,8,9)}$. The adenomyamatosis with irritative condition of gall bladder such as chronic inflammation or cholelithiasis ${ }^{(4)}$. In adenomymatosis there is proliferation of the mucosa and thickening of muscle wall. This will cause proliferation epithelial and invagination and diverticula which penetrate the muscular layer it is called ROKITANSKY ASCHOFF SINUSES ${ }^{(10)}$. There are no symptoms in adenomymatosis of gall bladder except for vague pain in abdomen, but there is cholelithiasis is present silent after cholecystectomy $^{(2)}$. Our case were operated for cholelithiasis.

Adenomymatosis of gall bladder is divided into three types. In generalized form there is diffuse thickening and irregularity of mucosal surface which give gland like structure in gall bladder wall. In segmental form compartementalization seen. In focal type lesion confined to fundus and usually present as a nodule bulging into lumen ${ }^{(4)}$. The clinical implication of adenomyamatosis are controversial about $70 \%$ of symptomatic patient present with gall stones, In residual $30 \%$ of patient with symptomatic but acalculous adenomyomatosis. The typical radiological appearance of adenomyomatosis is very helpful in obtaining a correct diagnosis. USG is the method of choice as it is inexpensive and practical ${ }^{(14)}$.All patient with symptomatic adenomyomatosis or with gall bladder lesions suggestive of adenomyomatosis but indistinguishable from premalignant or malignant lesions are consider as an indication for cholecystectomy ${ }^{(15)}$. Our patient, who present with a symptom complex similar to that of acalculous cholecystitis, was immediately relived after cholecystectomy, which was performed laproscopically.

\section{CONCLUSION}

Adenomyamatosis of gall bladder is incidental finding on USG. Adenomyomatosis give rise to symptoms like cholecystitis. Most of adenomyomatosis is discovered on excised gall bladder specimen of cholelithiasis. The treatment for adenomyomatosis of gall bladder is by laproscopic approach whenever possible. The main aim of this paper is we can add in differential diagnosis of adenomymotosis of gallbladder in case of pain in abdomen. Patient can present with features of acute cholecystitis but in case of adenomymatosis of gall bladder cholecystectomy should be considered before conservative treatment. 


\section{REFERENCES}

1. Mills SE. Gallbladder,extrahepatic biliary tree and ampulla. In; Mills SE, Senior editors,Steinbergs diagnostic surgical pathology y. ed. Philadelphia; Lippncott Williams and wilkins 2004;1775-1828

2. Albores-Saavedra J, Henson DE, Klimstra DS, Tumors of the gallbladder, extrahepatic bile duct and ampulla of vatar, atlas of tumor pathology, $3^{\text {rd }}$ series fascicle 27 AFIP, 2000 Washington, DC

3. Christensen $\mathrm{AH}$,Ishak $\mathrm{KG}$,Benign tumor and pseudotumor of gallbladder report of 180 cases Arch Pathol 1970;90(5);423-432

4. Handra-Luca A,Terris B, Couvelard A, Bonte H, Flejou JF,Adenomyoma and Adenomyomatous hyperplasia of the Vaterian System; clinical pathological and new immunohistochemical features of 13 cases, Mod Pathol 2003;16(6);530-536

5. Colovic R, Micev M, Markovic J,Zogovic $\mathrm{S}$, Colovic N, Stojkovic M. Adenomyoma of common hepatic duct HPB (OXFORD) 2002;4(4);187-19.

6. Sermon, J Himpens, G leman symptomatic adenomyomatosis of gallbladder report of a case Acta Chir belg,2003,103,225-229

7. Jutras JA, Longtin J. M, Levesque HP. Hyperplastic cholecystoses Hickey lecture AJR, 1960,83;795-827

8. Jutras J. A.,Levesque H. P.,Adenomyoma and adenomyomatosis of the gallbladder; Radiologic and pathologic correlations, Rad clin N Amer,1966,4;483-500

9. Jutras M,The cholesteroloses in;Bockus H.L.(ed)gastroenterology $3^{\text {rd }}$ ed vol II Philadelphia; WB sawnders 1976;816-827

10. Berk R.N.,Vander Vegt, J.H. Lichtenstein J.E. the hyperplastic cholecystoses; cholesterolosic and adenomyomatosis radiology,1983;146;593-601

11. Meguid M.M,Aunf, Barford M.L., adenomyomatosis of the gallbladder, Am J sura 1984,147(2);260-2
12. Kasahara Y.,Sonohe N.,Jomiyoshi H, et al adenomyomatosis of the gallbladder; a clinical survery of 30 surgically treated patients Nippon geka hokan,1992; 61(2);190-8

13. Halpert R.D., Bed D.G. Tiraman P.J., Gore D.C. Segmental adenomyomatosis of the gallbladder A, radiologic sonographic and pathologic correlation, Am surg, 1989,55 (9);570-2

14. Ram MD,Midh D, Adenomyomatosis of the gallbladder surgery $1975 ; 78(2) ; 224-$ 229

15. Alberti D,Calleaf, Camoni G, Falchetti D,Rigamonti W, Caccia G, ADENOMYOMATOSIS OF THE GALLBLADDER IN CHILHOOD, J ped. Surg,1998,33;1411-2. 